\title{
Debt Tax Benefits in a High Tax Emerging Market: Evidence from Brazil
}

Submitted 20/02/20, 1st revision 25/03/20, 2nd revision 18/03/20, accepted $31 / 03 / 20$

\section{Peter Vaz da Fonseca ${ }^{1}$, Michele Nascimento Jucá ${ }^{2}$, Wilson Toshiro Nakamura ${ }^{3}$}

\begin{abstract}
:
Purpose: This study hypothesizes that tax benefits encourage the use of third-party capital, and seeks to verify whether the tax benefit deriving from debts has a positive effect on Brazilian companies' capital structure.

Approach/Methodology/Design: Data on 259 nonfinancial companies over the period 20082018 are extracted from the Standard \& Poor's Capital IQ database and are analyzed through regression with dynamic data panel. The variables considered as tax benefit proxies are: marginal tax rate, kink, standardized kink and tax payment.The investigations comprise: trade off theory, pecking order theory, information asymmetry, bankruptcy costs and agency theory.

Findings: A positive debt effect on capital structure, taxation as providing a systematic incentive for greater leverage, and that, Brazilian companies, despite the country's heavy tax burden, are not taken full advantage of debt tax benefits. The study offers new evidence as to the speed of adjusting the indebtedness level relating to an optimal capital structure target. Brazilian companies have ground to contract more debt and maximize their tax benefit.

Practical Implications: The study will contribute positively to the understanding of influence of high tax emerging market for the government, academia, banks, industry, managers, regulators, investors and other users.

Originality/value: This study innovates by using MTR, kink and standardized kink to find debt tax benefits affecting emerging market companies' capital structure.
\end{abstract}

Keywords: Capital structure, tax benefit, kink, dynamic panel, corporate finance.

JEL: G32, H21, C33, O54, G30.

Paper Type: Research article.

\footnotetext{
${ }^{1}$ Department of Business, Mackenzie Presbyterian University, e-mail: peterfonseca67@gmail.com

${ }^{2}$ Department of Business, Mackenzie Presbyterian University, e-mail: michele.jucá@mackenzie.br

${ }^{3}$ Department of Business, Mackenzie Presbyterian University, e-mail: wilson.nakamura@mackenzie.br
} 


\section{Introduction}

The seminal paper by Modigliani and Miller, henceforth MM, (1958), affirms that the financing structure is irrelevant to the company's value, establishing, from this proposition, the basis of the modern theory of capital structure - the ratio between financial leverage and equity. Such statement presupposes a perfect world in which no attritions such as taxes exist. After criticism of their assumptions, MM (1963) review the premise of the nonexistence of taxes for the legal entity and they complement the previous statement. They recognize that the tax benefits on debt increase the company's value, indicating that companies should pursue a higher degree of leverage. The existence of tax benefit on debts, in turn, is related to the traditional theory which states that there is an optimal capital structure. According to Durand (1952), it is possible to define an optimal capital structure enabling maximization of shareholder's wealth. Empirically, companies tend to behave as if there is an optimal structure, however, since the pioneering work by Durand (1952), the determinant factors for such remains an open matter (Barclay, Heitzman and Smith, 2013; Thalassinos et al., 2015a; 2015b; Thalassinos and Stamatopoulos, 2015).

According to Chod and Zhou (2013), the introduction of interest payments deductibility creates an advantage for financing by means of debt rather than equity. Clemente-Almendros and Sogorb-Mira (2017) consider that the debt tax benefits are the tax savings resulting from the interest deduction from taxable incomes. When deducting interest, the company reduces its tax liabilities at the corporate marginal tax rate. Some empirical studies, including Miller (1977), DeAngelo and Masulis (1980), find no influence of taxes on the capital structure. Based on this, in his wellknown presidential speech at the American Finance Association, Myers (1984) declares that he wonders how corporations define their capital structures, since there is no study which clearly demonstrates what predictable and material effects are on their debt policy. However, more recent papers by Fan, Titman and Twite (2012), Faccio and $\mathrm{Xu}$ (2015), establish a solid statistical connection between taxes and capital structure.

A firm's optimal debt ratio is usually viewed as determined by a tradeoff between costs and borrowing benefits, holding the firm's assets and investment plans constant (Ugurlu et al., 2014). The firm is portrayed as balancing the value of interest tax shields against various costs of bankruptcy or financial constraints. There is controversy about how valuable the tax shields are, and which, if any, of the costs of financial constraints are material. Nevertheless, these disagreements give only variations on a theme. According to Myers (1984), Bartholdy and Mateus (2011) and $\mathrm{Li}$, Whited and $\mathrm{Wu}$ (2016), a firm is supposed to substitute debt for equity and vice versa, until the firm's value is maximized. In the current scenario of strong commercial competition, managers have been using global business platforms - with different levels of taxation - as a strategy for value creation (Tian, 2018). To make companies more competitive, executives attempt to optimize tax benefit through 
indebtedness. In this context, Brazil, as an emerging country, has particular characteristics that could make it play a relevant role in the international market, based on its competitive advantages.

When considering the high taxation level of companies in Brazil, direct taxes have an evident significant influence on their capital structures (Locatelli, Nasser \& Mesquita, 2015). According to Pessôa, Muniz da Silva and Abreu Campanário (2011), the Brazilian tax burden is one of the main variables that prevent resuming investment growth in the country. Oliveira and Gonçalves (2015) consider that taxes are a key concern of executive officers because they increase companies' costs hence reducing profits, which directly affects their competitiveness in the market. Studies conducted in other countries, regarding trade-off theory (TOT), indicate a positive relationship between the level of indebtedness and the tax benefit, obtained by using variables and proxies, including: a) the marginal tax rate (MTR); b) kink (KI); and c) tax payment (TP) - For details on these variables, see Heider and Ljungqvist (2015); Hebous and Ruf (2017) on MTR; Graham (2000); Bartholdy and Mateus (2011), on KI; Devereux, Maffini and Jing (2015); Faccio and Xu (2015), on TP. Moreover, some Brazilian papers considering only the effective tax paid present positive results for this relationship (Choi, Saito, \& Silva, 2015; Martinez \& Martins, 2016). Therefore, the purpose of this paper is to verify whether tax benefit deriving from debts has a positive effect on Brazilian companies' financial leverage.

This paper differs from the existing literature by considering variables and tax proxies that, far as is known, have not yet been tested in emerging market, including MTR and KI at the same time. Thus, the main hypothesis is that tax benefits encourage the use of third-party capital. A sample of 259 nonfinancial companies is analyzed by using a regression with dynamic panel data and GMM (Generalized Method of Moments) estimator in the attempt of eliminating endogeneity problem, as further discussed in Equation 3. The annual data are obtained from the Standard and Poor's (S\&P) IQ Capital database, for the period 2008-2018. The results confirmed the proposed hypothesis of the tax benefit arising from debts affecting the companies' capital structure. Additionally, Brazilian companies are verified as adopting a conservative stance at the use of their debts, to capture the benefits of tax deductions. According to Graham (2000), a KI greater than one is characterized as a conservative position, at which the company does not optimize its level of leverage, leaving room for improved use of this resource.

\section{Literature Review}

Graham, Leary and Roberts (2015) consider that companies' capital structure is one of the most important topics in corporate finance theory. In particular, this refers to the way companies finance their assets when using equity, which represents the resources provided by the shareholders, or the capital of third parties, which are the resources obtained through debt. The seminal studies on capital structure originated in the 1950's. There are two major opposing theories - the traditional theory (Durand 
1952) and the propositions by MM (1958). Durand (1952) considers that there is an optimal combination of indebtedness and equity maximizing the company's value. According to the traditional theory, the capital structure influences this value, because the cost of third-party capital is altered depending on the risk presented by the company. In other words, risk increases as the company increases its debt. MM (1958) disagree with the position by Durand (1952). Their propositions state, first, that the company's value is a function of its real assets, regardless of the origin of the financing that makes such investments feasible, and second, that the expected return of a share is positively related to the indebtedness degree, because the risk to shareholders grows with debt. However, these propositions are built on assumptions, especially on the existence of perfect capital markets and the absence of taxes on company 's incomes. In 1963, MM reviewed the reality of their assumptions regarding tax and began to consider the financing tax advantages through debt.

Subsequently, new theories were derived from these seminal papers and from the process of questioning the assumptions on which MM's propositions were based. These new theories pointed to new relations influencing the capital structure, including trade-off theory (TOT), pecking order theory (POT), information asymmetry, bankruptcy costs and agency theory. The hypotheses in this paper are based on these theories regarding the determinants of capital structure. According to Miller (1977) and Myers (1984), TOT shows the existence of an optimal level of indebtedness reached by companies as a result of a balance between tax benefits and debt costs. In this theory, tax benefits encourage the use of third-party capital (hypothesis 1 - hereafter H1) and debt costs result from the probability of a company's default, which may occur as a result of greater indebtedness.

For $\mathrm{Li}$, Whited and $\mathrm{Wu}$ (2016), TOT is constituted from the combination of tax savings, debt use and bankruptcy costs, deriving from the companies' indebtedness process. POT by Toy, Stonehill, Remmers, Wright and Beekhuisen (1974), proposes companies preferring to finance spending from their own sources. Thus, firms with lower growth potential should not hold debt, assuming that internally generated resources are sufficient to finance existing growth opportunities. Bartholdy and Mateus (2011), consider that POT indicates that more profitable companies (PR) contract less debt, because profit is used as the financing first source. In contrast, less-profitable companies end up by holding debt to finance their projects. Similarly, the most profitable companies (PY) seek less for third-party capital, because they can finance their spending with internally generated funds.

The theory of information asymmetry proposes that capital structure decisions are taken in the context of imbalance between the information held by the company and those held by investors (Myers, 1984; Myers and Majluf, 1984). For Miller (1977) and DeAngelo and Masulis (1980), given a certain level of indebtedness, the debt tax benefit is nullified by the increased risk of bankruptcy. Altman (1968) develops a forecast model, known as Z-Score, to assess the probability of corporate bankruptcy. Bartholdy and Mateus (2011) find a negative correlation between Altman's Z-Score 
(ZA) and the indebtedness levels. According to these authors, if bankruptcy is expensive, then the amount of debt should be a decreasing function of the bankruptcy probability.

Bartholdy and Mateus (2003) study the influence of corporate taxes on capital structure in a country where bank financing is the main external source of financing. The target capital structure adjustment model is studied with a sample of 929 Portuguese companies, from 1992 to 1999. There is statistical significance between the tax benefit of debt and the existence of deferred taxes, with influence on the company 's capital structure. In particular, a 10\% increase in the marginal tax rate leads to a $1.36 \%$ increase in long-term bank loans. Campos and Nakamura (2015) use a sample of US companies to estimate the medians of 64 sectors through a balanced panel over a 20-year period. The marginal tax independent variable (MTR) is the proxy developed by Graham (1996a; 1996b), which considers the marginal effect prior to financing decisions to avoid endogeneity problems.

According to the authors, the results - statistically significant - present a positive relationship between MTR and Altman's Z-Score with indebtedness. Devereux et al. (2015) examine how corporate capital structure is affected by the corporate income tax system and by the identification strategy, based on the variation of corporate marginal tax rates, due to the existence of kinks in the corporate tax rate schedule. The study sample covers a universe of 16,124 companies presenting income tax statement in UK, with 93,259 annual observations, during the period from 2001 to 2010. The authors use balance sheet information to construct the leverage ratio, defined as the sum of short and long-term debt, expressed as a proportion of total debt to book value. Through a dynamic capital structure adjustment model, they find a positive and statistically significant long-term fiscal effect on companies' financial leverage. For them, companies adapt their capital structures gradually in response to changes in the marginal tax rate.

Heider and Ljungqvist (2015) investigate changes in corporate income tax in US states and conclude that taxes have a first order effect on capital structure. The result is consistent with dynamic TOT and, according to the authors, the effect is asymmetric, as leverage does not respond to tax cuts. Fiscal sensitivity is higher among profitable companies with investment grade which, respectively, has a higher marginal tax benefit and lower marginal cost of debt issuance. Their study is conducted through a natural experiment between 1989 and 2011. According to the authors, companies replace debt with equity when tax rates rise. On the other hand, they keep leverage unchanged when tax rates are lowered. This asymmetry favors dynamic TOT models. The authors find statistical significance for the variables marginal tax and size in relation to indebtedness.

As far as profit taxation in Brazil is concerned, according to Godoi, Catarino, Melo and Garcia (2017), companies opt for a taxation regime that can be based on real profit, presumed profit, arbitrated profit or the simplified taxation system. The real 
profit regime is mandatory for companies with annual revenues exceeding US\$ 38.51 million, based on their net income for the year (Law no.12,814/2013). This regime allows the interest deductibility on indebtedness, i.e., the tax benefit (Decree no. 3,000/1999). Tax is calculated based on earnings before income tax (EBT), adjusted by additions, exclusions and compensations. Based on this result, on taxable profit incises the specified percentages of corporate taxes, which may be as high as 34\%, the maximum statutory income tax rate in Brazil (Oliveira and Gonçalves, 2015). Zani, Leites and Macagnan (2014) study the influence of interest on equity, as a tax benefit, on the capital structure of Brazilian companies, as it can be considered as financial expenses and is deductible for corporate tax purposes. They analyze 370 publicly traded companies from various industries through panel data, over the period from 1998 to 2006. According to the authors, companies that pay interest on equity use less capital from third parties. Lara and Mesquista (2008) investigate 70 companies from 1995 to 1998 and 1999 and 2001 and find no deterministic relationship between interest on equity and Brazilian companies' capital structure.

\section{Methodological Procedures}

The main hypothesis of this work is whether there is a positive relationship between the tax benefit of debt and corporate indebtedness. This hypothesis is divided into three parts relating to each variable or tax proxy, so that hypotheses H1a, H1b and H1c correspond to MTR, KI, and TP. Then, additional control variables contribute to determine the equilibrium of the model. These hypotheses are verified by a regression model, using unbalanced dynamic panel data, as shown in Equation 3.

The initial sample was composed of 499 Brazilian nonfinancial corporations. From these, 132 foreign companies were excluded for being funded by Brazilian depositary receipts. Other 28 companies were excluded because their levels of indebtedness exceeded their total assets, so they accumulated losses. Finally, 80 companies were excluded for insufficient data in the examined period. Thus, the final sample consists of 259 public companies, resulting in 2,189 observations between the years of 2008 and 2018. The year of 2008 was selected as the starting date for the analysis because it marks the commencement of Law no. 11,638/07, which harmonizes Brazilian accounting policies with International Financial Reporting Standards. Data are obtained from S\&P's IQ Capital database and are analyzed by using Stata econometric software, version 15.

The proxies associated with debt tax benefit or the independent variables are MTR, KI, and TP. The calculation of MTR incorporates the effects of deductions and tax credits. If a company has extra debt tax benefits, sufficient to lower its expected MTR, then the company issues less debt than does an identical company without these benefits. Recent studies identify some of the companies referring to the expected average tax rate, when making capital structure decisions, rather than the official tax rate (Graham et al., 2015). Graham (1996b) considers that, although 
being difficult to calculate, the simulated tax rate used by Shevlin (1990) and Graham (1996a) is the best available proxy for the "true" MTR. However, if the simulated tax rate is unavailable, a trichotomous variable should be calculated in preference to the most commonly used tax variables (Graham 1996b). This paper uses a trichotomous variable, which is obtained on: i) the maximum statutory income tax rate of Brazilian companies (34\%), if the company has no deferred tax or negative taxable income; ii) half the maximum statutory income tax rate (17\%), if the company has either deferred tax or negative taxable income, but not both; and iii) a zero rate $(0 \%)$, if the company has negative taxable income and deferred tax (Graham, 1996b).

$\mathrm{KI}$ is a tax variable that allows determining whether companies use debt as a tax benefit. In some studies, it is used as a tax variable to analyze its effect on companies' indebtedness levels (Graham, 2000; Bartholdy and Mateus, 2011). Companies with positive earnings after interest payments can raise their debt level and, with interest payments, achieve marginal tax benefits equal to the nominal tax rate. However, for companies with negative earnings after interest payments, the marginal benefits of a debt increase are lower than the statutory rate (Graham, 2000). To measure these effects, the KI variable is used, i.e., the amount of interest required to make earnings equal to zero. If KI is less than one, the profit before taxes is less than interest actually paid. In this case, the profit after interest is negative. This represents an aggressive indebtedness policy. However, if $\mathrm{KI}$ is greater than one, the profit after interest is positive and the company uses debt more conservatively. According to Graham (2000), the KI variable is the result of the ratio between Earnings Before Interest and Taxes (EBIT) and the interest paid on debts, as shown in Figure 1.

Figure 1. Relationship between debt marginal tax benefit and kink

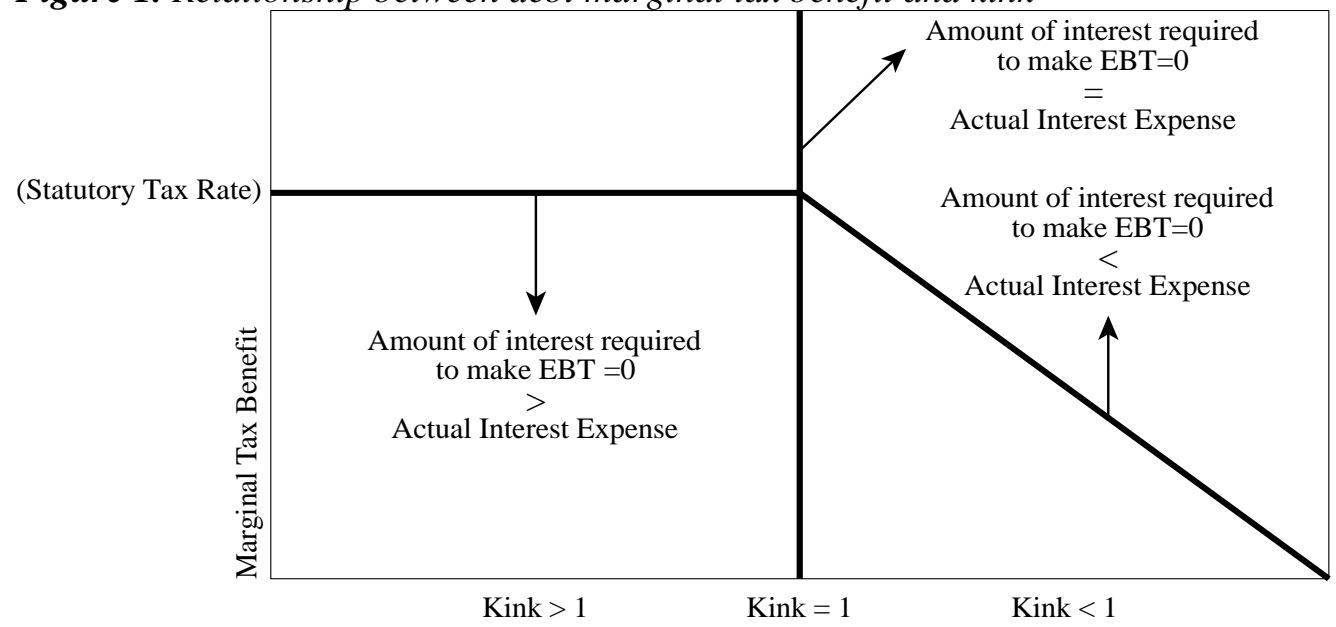

Source: From "Debt and Taxes For Private Firms" by Bartholdy and Mateus, 2011, International Review of Financial Analysis, 20(3), p. 182. 
Notes:

Kink $=1$ if target interest $=$ actual interest.

Kink $<1$ if EBT < interest paid. This is an aggressive policy.

Kink > 1 if EBT > interest paid. This is a conservative policy.

Following Graham (2000), the KI is calculated as shown in Equation 1. Interest paid is equal to interest expenses paid in the period.

$$
\mathrm{KI}=\frac{\mathrm{EBIT}}{\text { Interest Paid }}
$$

Figure 2 further clarifies this concept using a numerical example based on the average values of this sample. When EBIT is equal to US\$ 530 million and interest paid is US\$ 157 million, the KI value is 3.36 (530/157), i.e., $\mathrm{KI}$ is greater than one. In this case, the tax benefit leveraged by companies is US\$ 53 million (US\$ 157 million times the tax rate of 34\%). This indicates that Brazilian companies currently adopt a conservative policy. They could increase their debt cost up to $236 \%$ by paying additional interest of US\$ 373 million - associated with US\$ 127 million tax - to obtain the maximum tax deduction benefit, thus achieving a KI equal to one (530/530). In this circumstance, the maximum possible tax benefit for companies is US\$ 180 million (US\$ 530 million times the $34 \%$ tax rate). However, if the interest paid exceeds US\$ 530 million, that is, if it is above EBIT, KI becomes greater than one.

Figure 2. Numerical example of the relationship between the debt marginal tax benefit and the kink of the Brazilian companies in the sample (US\$ million).

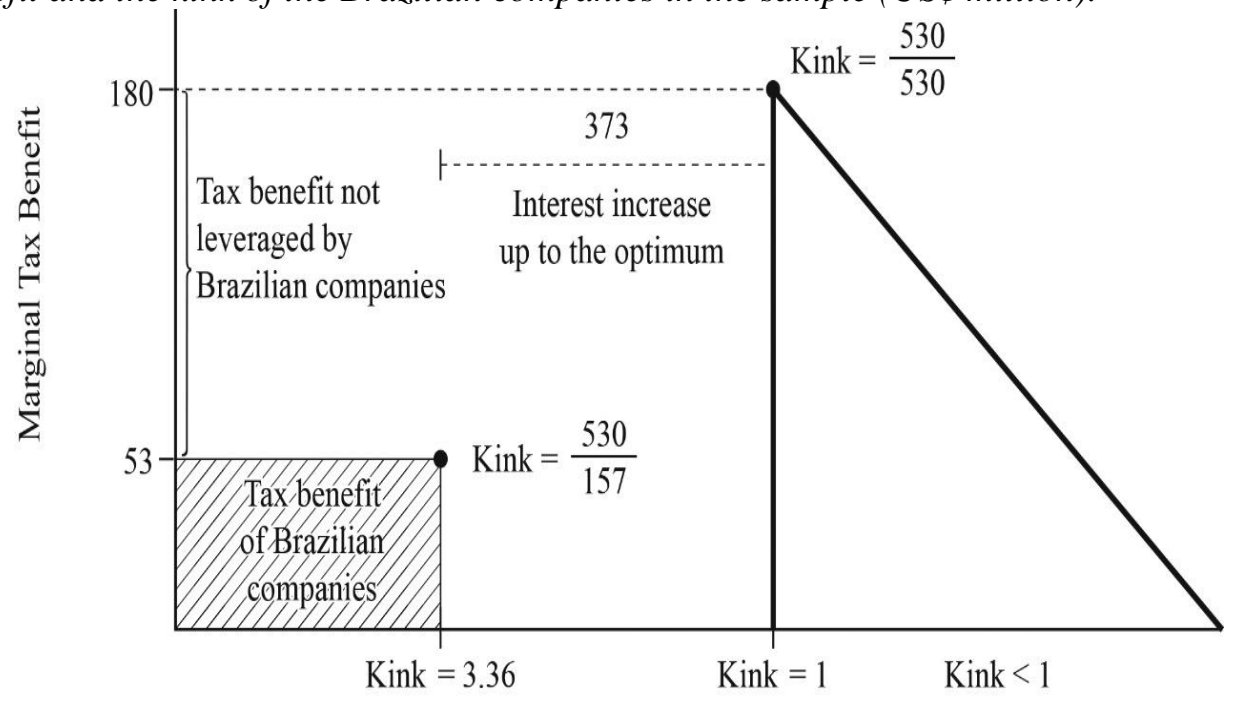

According to Graham (2000), a company with these values can take on more debts and maximize its tax benefit. Finally, following Graham (2000), the variable for the TP level is calculated as shown in Equation 2: 


$$
\mathrm{TP}=\frac{\text { Paid Value of Taxes }}{\text { EBT }}
$$

According to Devereux et al. (2015), the results found in the literature provide evidence that firms adapt their capital structure in response to changes in their tax rate over time and, therefore, it is more appropriate to estimate a model of capital structure adjustment. The regression model with dynamic panel is characterized by considering the inclusion of the dependent variable, as a regressed lag, which is obtained using Equation 3 (Wooldridge, 2016), where $\mathrm{L}_{\mathrm{it}}$ is the debt level of firm $i$ at time $t ; \gamma$ is the target adjustment coefficient; $\alpha$ is the constant term; $\beta_{\operatorname{tax}}$ is the estimated coefficient for tax variables; TAX $_{i t}$ is the tax variable; $\beta_{z}$ is the estimated coefficient of control variables; $C_{i t}$ is the vector of control variables and $\varepsilon_{i t}$ is the term of error. The model variables are presented in Table 1.

$$
\mathrm{L}_{\mathrm{it}}=\gamma \alpha+\gamma \beta_{\mathrm{tax}}+\mathrm{TAX}_{\mathrm{it}}+\gamma \beta_{\mathrm{z}} \mathrm{C}_{\mathrm{it}}+(1-\gamma) \mathrm{L}_{\mathrm{it}-1}+\varepsilon_{\mathrm{it}}
$$

\begin{tabular}{|c|c|c|c|c|c|c|c|}
\hline $\begin{array}{l}\text { I } \\
\text { n } \\
\text { it } \\
\text { ia } \\
\text { ls }\end{array}$ & $\begin{array}{l}\text { Hy } \\
\text { p }\end{array}$ & Name & $\begin{array}{l}\text { Type of } \\
\text { variabl } \\
\text { e }\end{array}$ & $\begin{array}{l}\text { The } \\
- \\
\text { ory }\end{array}$ & $\begin{array}{l}\text { E } \\
\text { xp } \\
\dot{S i} \\
\text { gn }\end{array}$ & Formula & Components \\
\hline $\mathrm{L}$ & & $\begin{array}{l}\text { Debt } \\
\text { level }\end{array}$ & $\begin{array}{l}\text { Depend } \\
\text { ent }\end{array}$ & n.a. & $\begin{array}{l}\text { n. } \\
\text { a. }\end{array}$ & $\begin{array}{l}\mathrm{L}=\text { Debt/Total } \\
\text { assets }\end{array}$ & $\begin{array}{l}\text { Debt }=\text { short and long term } \\
\text { debts } \\
\text { Assets = total assets }\end{array}$ \\
\hline $\begin{array}{l}\mathrm{M} \\
\mathrm{T} \\
\mathrm{R}\end{array}$ & $\begin{array}{l}\mathrm{H} 1 \\
\mathrm{a}\end{array}$ & $\begin{array}{l}\text { Marginal } \\
\text { tax rate }\end{array}$ & $\begin{array}{l}\text { Indepen } \\
\text {-dent }\end{array}$ & $\begin{array}{l}\text { TO } \\
\text { T }\end{array}$ & + & $\begin{array}{l}\text { MTR } \\
\text { Trichotomous } \\
\text { proxy, whose } \\
\text { assigned value can } \\
\text { be } 0 \%, 17 \% \text { or } \\
34 \%\end{array}$ & $\begin{array}{l}\text { i) maximum statutory tax } \\
\text { rate }(34 \%) \text {, if company has } \\
\text { no deferred tax or negative } \\
\text { taxable income; } \\
\text { ii) half the maximum } \\
\text { statutory tax rate }(17 \%) \text {, if } \\
\text { company has deferred tax or } \\
\text { negative taxable income, but } \\
\text { not both; and, } \\
\text { iii) zero (0\%), if company } \\
\text { has negative taxable income } \\
\text { and deferred tax. }\end{array}$ \\
\hline $\begin{array}{l}K \\
I\end{array}$ & $\begin{array}{l}\mathrm{H} 1 \\
\mathrm{~b}\end{array}$ & Kink & $\begin{array}{l}\text { Indepen } \\
\text {-dent }\end{array}$ & $\begin{array}{l}\text { TO } \\
\text { T }\end{array}$ & - & $\begin{array}{l}\mathrm{KI}=\mathrm{EBIT} / \text { Interest } \\
\text { paid }\end{array}$ & $\begin{array}{l}\text { EBIT = earnings before } \\
\text { interest and } \\
\text { Interest paid }=\text { interest } \\
\text { expenses paid in the period }\end{array}$ \\
\hline $\begin{array}{l}\mathrm{T} \\
\mathrm{P}\end{array}$ & $\begin{array}{l}\mathrm{H} 1 \\
\mathrm{c}\end{array}$ & $\begin{array}{l}\text { Tax } \\
\text { Payment }\end{array}$ & $\begin{array}{l}\text { Indepen } \\
\text {-dent }\end{array}$ & $\begin{array}{l}\text { TO } \\
\mathrm{T}\end{array}$ & + & $\begin{array}{l}\mathrm{TP}=\text { Paid value of } \\
\text { taxes/ EBT }\end{array}$ & $\begin{array}{l}\text { Paid value }=\text { paid values of } \\
\text { corporate taxes } \\
\text { EBT }=\text { earnings before taxes }\end{array}$ \\
\hline $\begin{array}{l}\mathrm{P} \\
\mathrm{Y}\end{array}$ & n.a & $\begin{array}{l}\text { Profitabil } \\
\text { ity (yield) }\end{array}$ & Control & $\begin{array}{l}\mathrm{PO} \\
\mathrm{T}\end{array}$ & - & $\mathrm{PY}=\mathrm{EBIT} /$ Assets & $\begin{array}{l}\text { EBIT = earnings before } \\
\text { interest and taxes } \\
\text { Assets = total assets }\end{array}$ \\
\hline & & & & & & & NI $=$ net income for the \\
\hline
\end{tabular}

Table 1. Variables of the econometric model 


\begin{tabular}{|c|c|c|c|c|c|c|c|}
\hline $\begin{array}{l}\mathrm{P} \\
\mathrm{R}\end{array}$ & n.a & $\begin{array}{l}\text { Profitabil } \\
\text { ity }\end{array}$ & Control & $\begin{array}{l}\mathrm{PO} \\
\mathrm{T}\end{array}$ & - & $\mathrm{PR}=\mathrm{NI} /$ Sales & $\begin{array}{l}\text { period } \\
\text { Sales = total sales for the } \\
\text { period }\end{array}$ \\
\hline $\begin{array}{l}\mathrm{T} \\
\mathrm{Q}\end{array}$ & $\begin{array}{l}\text { n.a } \\
\text {. }\end{array}$ & $\begin{array}{l}\text { Tobin's } \\
\text { Q }\end{array}$ & Control & $\begin{array}{l}\mathrm{PO} \\
\mathrm{T}\end{array}$ & + & $\mathrm{TQ}=\mathrm{TL} / \mathrm{MV}$ & $\begin{array}{l}\text { MV - Maket value } \\
\text { TL= total liabilities } \\
\text { MV= Market value }\end{array}$ \\
\hline $\begin{array}{l}\mathrm{Z} \\
\mathrm{A}\end{array}$ & $\begin{array}{l}\text { n.a } \\
\text {. }\end{array}$ & $\begin{array}{l}\text { Z-Score } \\
\text { Altman }\end{array}$ & Control & $\begin{array}{l}\text { Ban } \\
\mathrm{k} \\
\text { rupt } \\
\text { cy }\end{array}$ & - & $\begin{array}{l}\mathrm{Z}=(1.2 * \mathrm{X} 1)+ \\
(1.4 * \mathrm{X} 2)+ \\
(3.3 * \mathrm{X} 3)+ \\
(0.6 * \mathrm{X} 4)+(1 * \mathrm{X} 5)\end{array}$ & $\begin{array}{l}\mathrm{X} 1=\text { working capital } / \text { total } \\
\text { assets } \\
\mathrm{X} 2=\text { retained earnings } / \text { total } \\
\text { assets } \\
\mathrm{X} 3=\mathrm{EBIT} / \text { total assets } \\
\mathrm{X} 4=\text { market value of equity } \\
\text { / book value of demanded } \\
\text { liabilities } \\
\mathrm{X} 5=\text { sales / total assets }\end{array}$ \\
\hline $\begin{array}{l}\mathrm{I} \\
\mathrm{E}\end{array}$ & n.a & $\begin{array}{l}\text { Interest } \\
\text { on equity }\end{array}$ & Control & $\begin{array}{l}\mathrm{PO} \\
\mathrm{T}\end{array}$ & - & $\begin{array}{l}\mathrm{IE}=\mathrm{IE} \text { payment } \\
\text { Dummy }\end{array}$ & $\begin{array}{l}\text { Where: } \\
0=\text { if company pays no } \\
\text { interest on equity } \\
1=\text { if company pays interest } \\
\text { on equity }\end{array}$ \\
\hline
\end{tabular}

Notes. n.a. $=$ non applicable. TOT denotes trade-off theory and POT denotes pecking order theory

\section{Analysis of Results}

Table 2 describes the main characteristics of the dependent, independent and control variables relating to the main hypothesis. The Brazilian companies have an average $\mathrm{L}$ value of 0.29 . Average $\mathrm{KI}$ of 3.36 indicates that companies can increase tax deductions of interest expenses. Doing so, kink value would equal to one, which characterizes the debt tax optimization (as shown in Figure 1).

Table 2. Descriptive statistics

\begin{tabular}{|l|l|l|l|l|l|}
\hline Variables & $\begin{array}{l}\text { Observation } \\
\text { s }\end{array}$ & Average & $\begin{array}{l}\text { Standard } \\
\text { Deviation }\end{array}$ & Minimum & $\begin{array}{l}\text { Maximu } \\
\text { m }\end{array}$ \\
\hline L & 2308 & 0.29 & 0.18 & 0.00 & 0.82 \\
\hline MTR & 2308 & 18.43 & 9.95 & 0.00 & 34.00 \\
\hline KI & 1870 & 3.36 & 2,75 & 0.39 & 10.39 \\
\hline TP & 1709 & 0.24 & 0.11 & 0.01 & 0.50 \\
\hline PY & 2306 & 0.08 & 0.08 & -0.56 & 0.88 \\
\hline PR & 2287 & 0.12 & 0.50 & -4.72 & 3.98 \\
\hline QT & 2291 & 1.51 & 1.08 & 0.34 & 8.67 \\
\hline ZA & 2206 & 2.32 & 1.75 & -1.90 & 9.97 \\
\hline IE & 2307 & 0.42 & 0.49 & 0.00 & 1.00 \\
\hline
\end{tabular}

This table presents the descriptive statistics for the dependent, independent and control variables: $\mathrm{L}$ is the general indebtedness ratio calculated as the ratio of total debt to total assets; MTR is a tax proxy whose assigned value can be $0 \%, 17 \%$ or $34 \%$; $\mathrm{KI}$ is the ratio of EBIT to interest paid; $\mathrm{TP}$ is the ratio of paid value of taxes to EBT; PY is the ratio of EBIT to total assets; PR is the ratio of net income for the 
period to total sales for the period; TQ (Tobin Q) is the ratio of total liabilities to market value; ZA is Z-Score of Altman; IE is the interest on equity calculated thru a proxy where $0=$ if company pays no interest on equity and $1=$ if company pays interest on equity.

Table 3 presents the regression model's results using dynamic panel data. The values in square brackets represent the p-values or significance levels of coefficients. Four models are generated, as follow: model 1, which includes all independent tax variables, MTR, KI, and TP; model 2, including only MTR; model 3, which includes only KI; and model 4, including only TP. Regarding the dynamic panel assumptions tests, the Sargan test points to the null hypothesis acceptance that the instrumental variables (IV) are valid. According to Roberts and Whited (2013), IV try to eliminate the endogeneity by dropping the correlation between the explanatory variables and the error term. In turn, the Arellano and Bond (1991) test verifies the existence of serial correlation. The result points to the acceptance of the null hypothesis that there is a first-order serial correlation (p-value 0.0000) and a rejection of the same null hypothesis for the second order serial correlation. These results support the validation of all models (1-4) of the dynamic panels tested. The estimation through the Blundell and Bond (1998)'s system GMM allows to dynamically measure the system by reducing the effects of the variables omitted from dynamic equations (Flannery and Hankins, 2013).

To test robustness: i) Results of dynamic panel models are compared with static panel. In line with the literature, better models are generated in dynamic panel, suggesting that firms adapt their capital structure in response to changes in their marginal tax rate over time; ii) The models of the dynamic and static panels of the Brazilian companies are compared with the companies of Chile - important emerging country of Latin America and producer of commodities such as Brazil. The results confirm the conservative use of the tax benefit by Brazilian companies.

Concerning the independent tax variables at level, all proxies presented statistical significance at the $1 \%$ level. MTR presents the expected positive relation with the indebtedness variable, for models 1 and 2. In turn, KI presents the expected negative relation with the indebtedness variable for models 1 and 3 . In the case of TP, the positive sign has a statistical significance for models 1 and 4 . These results indicate that the debt tax benefits effectively influence the companies' capital structure, confirming the main hypothesis $(\mathrm{H} 1)$ of this study. The lagged dependent variable $\left(\mathrm{L}_{\mathrm{t}-1}\right)$ shows a positive sign and a statistical significance at the $1 \%$ level for all models. The high coefficient of the indebtedness lagged variable suggests a prolonged adjustment phase for Brazilian companies' capital structure, i.e., past debt has a high degree of influence on current debt. It can be confirmed by the Speed of Adjustment (SOA) - from $\Lambda 13.7 \%$ to $\Lambda 21.6 \%$. SOA determines the relevance of dynamic TOT (Frydenberg, 2011). Research on capital structure adjustment speed is an important issue to be researched. (Huang and Ritter, 2009).The lagged independent tax variables aim at verifying the existence of a relationship between 
the current indebtedness and its values in the immediately preceding period. Consideration of the dynamic element allows controlling for the possible correlation existence between the independent variable's past values and its contemporary values, thus eliminating potential sources of bias among these estimators. In this way, the first-difference lagged variables can be used as instruments for the level equation. The MTR's lagged tax variables have a positive sign, being consistent with theory, and are statistically significant for models 1,2 , and 4 . These results confirm the main hypothesis (H1) of this study. In addition, it is noted that the KI and TP tax variables experience a sign reversal when switching between the level variables and their lagged ones - with statistical significance at the $1 \%$ level - related to the general and specific models of each. This fact suggests the existence of a short-term adequacy dynamics of 1 year in relation to the capital structure.

Concerning the level control variables, in the case of PY, the positive relation is significant for all models at the $1 \%$ level. This result suggests that Brazilian companies define their capital structure based on TOT. QT has a positive relation, being significant at the $1 \%$ level only for model 4 . ZA shows a negative relation and is statistically significant at $1 \%$ level for all models. IE has a negative relation with indebtedness and statistical significance for all models at the $1 \%$ level, what suggests that high profit companies take advantage of the Brazilian taxation law.

Table 3. Regression with dynamic panel data

\begin{tabular}{|c|c|c|c|c|c|c|}
\hline $\begin{array}{l}\text { Variable } \\
\mathrm{s}\end{array}$ & \begin{tabular}{|l} 
Hypothese \\
$\mathrm{s}$
\end{tabular} & Expect sign & Model 1 & Model 2 & Model 3 & Model 4 \\
\hline $\mathrm{L}_{\mathrm{t}-1}$ & n.a & + & $\begin{array}{l}0.7924 \\
{[0.000]}\end{array}$ & \begin{tabular}{|l|}
0.8101 \\
{$[0.000]$}
\end{tabular} & $\begin{array}{l}0.7868 \\
{[0.000]}\end{array}$ & \begin{tabular}{|l|}
0.8630 \\
{$[0.000]$} \\
\end{tabular} \\
\hline MTR & H1a & + & $\begin{array}{c}0.0006 \\
{[0.000]} \\
\end{array}$ & \begin{tabular}{|l|}
0.0009 \\
{$[0.000]$} \\
\end{tabular} & $\mathrm{n} . \mathrm{a}$ & n.a \\
\hline $\mathrm{MTR}_{\mathrm{t}-1}$ & H1a & - & $\begin{array}{l}-0.0009 \\
{[0.000]}\end{array}$ & $\begin{array}{c}-0.0001 \\
{[0.766]} \\
\end{array}$ & n.a & n.a \\
\hline KI & H1b & - & $\begin{array}{r}-0.0102 \\
{[0.000]} \\
\end{array}$ & n.a & $\begin{array}{c}-0.0093 \\
{[0.000]} \\
\end{array}$ & n.a \\
\hline $\mathrm{KI}_{\mathrm{t}-1}$ & H1b & + & $\begin{array}{l}0.0081 \\
{[0.000]}\end{array}$ & n.a & $\begin{array}{l}0.0059 \\
{[0.000]}\end{array}$ & n.a \\
\hline $\mathrm{TP}$ & H1c & + & $\begin{array}{c}0.1667 \\
{[0.000]}\end{array}$ & n.a & n.a & \begin{tabular}{|l|}
0.1308 \\
{$[0.000]$} \\
\end{tabular} \\
\hline $\mathrm{TP}_{\mathrm{t}-1}$ & H1c & - & $\begin{array}{l}-0.0360 \\
{[0.000]}\end{array}$ & n.a & n.a & \begin{tabular}{|l|}
0.0253 \\
{$[0.219]$} \\
\end{tabular} \\
\hline PY & n.a & + & $\begin{array}{c}0.1459 \\
{[0.000]}\end{array}$ & \begin{tabular}{|l|}
0.1467 \\
{$[0.002]$}
\end{tabular} & $\begin{array}{c}0.3242 \\
{[0.000]}\end{array}$ & \begin{tabular}{|c|}
0.2502 \\
{$[0.000]$} \\
\end{tabular} \\
\hline PR & n.a & - & $\begin{array}{c}-0.0647 \\
{[0.000]} \\
\end{array}$ & \begin{tabular}{|l|}
0.0026 \\
{$[0.781]$} \\
\end{tabular} & $\begin{array}{r}-0.0347 \\
{[0.024]} \\
\end{array}$ & \begin{tabular}{|l|}
-0.0355 \\
{$[0.005]$} \\
\end{tabular} \\
\hline QT & n.a & + & $\begin{array}{c}-0.0071 \\
{[0.000]} \\
\end{array}$ & \begin{tabular}{|l|}
0.0031 \\
{$[0.392]$} \\
\end{tabular} & $\begin{array}{l}-0.0029 \\
{[0.476]} \\
\end{array}$ & \begin{tabular}{|l|}
0.0077 \\
{$[0.016]$} \\
\end{tabular} \\
\hline $\mathrm{ZA}$ & n.a & - & $\begin{array}{l}-0.0072 \\
{[0.000]}\end{array}$ & \begin{tabular}{|l|}
-0.0099 \\
{$[0.000]$} \\
\end{tabular} & $\begin{array}{l}-0.0068 \\
{[0.053]}\end{array}$ & \begin{tabular}{|l|}
-0.0159 \\
{$[0.000]$} \\
\end{tabular} \\
\hline
\end{tabular}




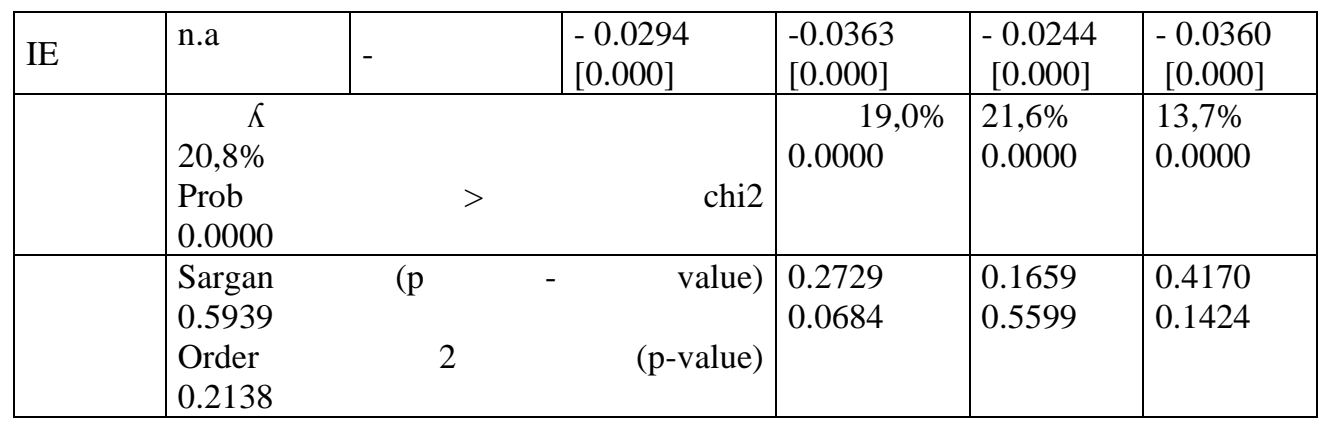

\section{Source: Authors' calculations.}

Notes: n.a = not applicable. The values in square brackets represent the level of statistical significance of the relation, whereas those in bold font represent the variables with statistical significance and the theoretically predicted sign.

This table reports results from GMM regressions analyses with total leverage at time t as dependent variable and independent variables: MTR is a tax proxy whose assigned value can be $0 \%, 17 \%$ or $34 \%$; $\mathrm{MTR}_{\mathrm{t}-1}$ is the lagged MTR variable; KI is the ratio of EBIT to interest paid; $\mathrm{KI}_{\mathrm{t}-1}$ is the lagged $\mathrm{KI}$ variable; $\mathrm{TP}$ is the ratio of paid value of taxes to EBT; $\mathrm{TP}_{\mathrm{t}-1}$ is the lagged $\mathrm{TP}$ variable. The control variables are: $\mathrm{PY}$ is the ratio of EBIT to total assets; PR is the ratio of net income for the period to total sales for the period; TQ (Tobin Q) is the ratio of total liabilities to market value; ZA is Z-Score of Altman; IE is the interest on equity calculated thru a proxy where $0=$ if company pays no interest on equity and $1=$ if company pays interest on equity.

Finally, Table 4 summarizes the results of the regression test hypotheses validity, using dynamic panel data. To corroborate the hypotheses of this study, a more conservative criterion is considered regarding the coherence of the signs with the theories and the statistical significance of the independent and control tax variables for model 1 and another specific model (2, 3, or 4). Based on this criterion, MTR, $\mathrm{KI}$, and TP confirm the hypothesis $\mathrm{H} 1$ for models $1,2,3$, and 4 . Therefore, regarding the research problem of this study, a positive relation between debt tax benefit and companies' indebtedness is found.

Table 4. Validation of the regression model test hypotheses-summary

\begin{tabular}{|c|c|c|c|c|c|c|c|c|}
\hline \multirow{2}{*}{$\begin{array}{l}\text { Variab } \\
\text { les }\end{array}$} & \multirow{2}{*}{$\begin{array}{l}\text { Hypothese } \\
\text { s }\end{array}$} & \multirow[t]{2}{*}{ Theory } & \multirow{2}{*}{$\begin{array}{l}\text { Expecte } \\
\text { d sign }\end{array}$} & \multicolumn{4}{|c|}{$\begin{array}{l}\text { Models of regression with } \\
\text { dynamic panel data }\end{array}$} & \multirow{2}{*}{$\begin{array}{l}\text { Confir } \\
\text { med } \\
\text { hypothe } \\
\text { sis }\end{array}$} \\
\hline & & & & 1 & 2 & 3 & 4 & \\
\hline MTR & H1a & TOT & + & Yes & Yes & n.a & n.a & Yes \\
\hline KI & $\mathrm{H} 1 \mathrm{~b}$ & TOT & - & Yes & n.a & Yes & n.a & Yes \\
\hline $\mathrm{TP}$ & H1c & TOT & + & Yes & n.a & n.a & n.a & Yes \\
\hline PY & n.a & TOT & + & Yes & Yes & Yes & Yes & Yes \\
\hline PR & n.a & POT & - & Yes & No & Yes & Yes & Yes \\
\hline
\end{tabular}




\begin{tabular}{|l|l|l|l|l|l|l|l|l|}
\hline QT & n.a & POT & + & No & No & No & Yes & No \\
\hline ZA & n.a & Bankruptcy & - & Yes & Yes & Yes & Yes & Yes \\
\hline IE & n.a & POT & - & Yes & Yes & Yes & Yes & Yes \\
\hline
\end{tabular}

Source: Authors' camputations.

Note: n.a = not applicable.

This table reports summary from regression model test hypotheses MTR is a tax proxy whose assigned value can be $0 \%, 17 \%$ or $34 \%$; MTR $_{\mathrm{t}-1}$ is the lagged MTR variable; $\mathrm{KI}$ is the ratio of EBIT to interest paid; $\mathrm{KI}_{\mathrm{t}-1}$ is the lagged $\mathrm{KI}$ variable; $\mathrm{TP}$ is the ratio of paid value of taxes to $\mathrm{EBT}$; $\mathrm{TP}_{\mathrm{t}-1}$ is the lagged $\mathrm{TP}$ variable. The control variables are: PY is the ratio of EBIT to total assets; PR is the ratio of net income for the period to total sales for the period; TQ (Tobin Q) is the ratio of total liabilities to market value; ZA is Z-Score of Altman; IE is the interest on equity calculated thru a proxy where $0=$ if company pays no interest on equity and $1=$ if company pays interest on equity

\section{Conclusion}

Capital structure is the most studied subject in finance, but researchers continue being challenged by the questioning of Myers (1984) on how firms choose their capital structure. Brazil faces a higher tax burden than most of its developing countries' competitors. In this context, this study aims at understanding whether tax benefits deriving from debt affect the capital structure of Brazilian nonfinancial companies. The main hypothesis is that there is a positive relation between debt tax benefit and corporate indebtedness. To verify this hypothesis, 259 nonfinancial companies in Brazil are analyzed in the period from 2008 to 2018 by means of regression analysis with dynamic panel data. The tax proxies are MTR, KI, and TP.

All proxies are found as statistically significant for all models, whether general or specific, with the expected sign of the theory. Regarding the independent variables, it is found that, for each independent variable, there is a reversal sign between the level variables and the lagged ones. This suggests the existence of adequacy dynamics of one year in relation to the capital structure. In addition, it is noted that Brazilian companies adopt a conservative stance at the use of their debts in capturing the tax deduction benefits. This result corroborates the studies by Graham and Tucker (2006) and Richardson, Lanis and Leung (2014).

Hypothesis that tax benefits positively influence Brazilian companies' indebtedness is confirmed for all models and proxies, which corroborates Choi et al. (2015) and Martinez and Martins (2016). MTR has statistical significance in both the general and the specific models. MTR is an important proxy developed by Graham (1996a; 1996b) to study the expectation of companies regarding the taxation of next profits and, thus, to better capture the relationship with indebtedness. KI shows a sign as predicted by the theory and it demonstrates statistical significance, both in the 
general model 1 and in the specific model 3. Its negative relation with indebtedness indicates that tax benefits are a driver in contracting third-party capital. However, for Brazilian companies to reach the optimum point $(\mathrm{KI}=1)$, they should increase their indebtedness by an additional up to $236 \%$ in interest payments $(\mathrm{KI}=3.36)$. This result corroborates Faccio and $\mathrm{Xu}$ (2015) and Tian (2018). TP presents a sign in accordance with the theory and is statistically relevant in the general and specific models. The positive relations of these tax variables with indebtedness reinforce the fact that tax benefits are a driver of corporate financial leverage. This result corroborates the studies by Devereux et al. (2015) and Clemente-Almendros and Sogorb-Mira (2017). Relating to the control variables, PY, ZA, and IE comply with the predicted signs and are statistically significant.

This paper innovates in using data in a dynamic panel, and adds to the existing literature by presenting new evidence, such as the speed of adjustment of the level of indebtedness towards an optimal capital structure target. In addition, tax proxies, not examined at the same time for emerging market companies, are applied in the research. The empirical findings are summarized as follows: a) in line with the previous research, taxation has a positive impact on the Brazilian companies' capital structure, suggesting that the tax system provides a systematic incentive for greater leverage; and b) despite the heavy tax burden, companies in Brazil adopt a conservative policy as to these tax benefits. As Graham (2000) comments, Brazilian companies, which are demanding the taxes reduction, are leaving money on the table.

There are limitations in this study. First, maybe other factors influence corporate indebtedness, such as government incentives through the granting of subsidized interest credit, which would reduce the need of using the tax benefit. Second, the existence of distinct economic scenarios, such as growth and crisis, is not considered and the model does not include macroeconomic variables. Third, this sample of companies comprises publicly traded companies, of which there is a reduced number in Brazil (499 companies).

It would be useful to understand the unlisted companies' capital decision, given their increasingly important role in the economy. Finally, a number of issues could be considered in future research, as follows: a) marginal tax rate calculation, i.e., application of Graham's simulated model (1996a, 1996b, 2000, 2003); b) comparisons of different company samples - e.g., large and medium/small sized companies or national and international ones - to analyze the tax benefit effect on their capital structures; c) understanding the influence of tax incentives, which could replace debt tax benefits on the level of companies' financial leverage; and, d) analysis of the tax benefit relationship relating to the short-term and long-term indebtedness. 


\section{References:}

Altman, E.I. 1968. Financial ratios, discriminant analysis and the prediction of corporate bankruptcy. The Journal of Finance, 23(4), 589-609.

Arellano, M., Bond, S. 1991. Some tests of specification for panel data: Monte Carlo evidence and an application to employment equations. The Review of Economic Studies, 58(2), 277-297.

Barclay, M.J., Heitzman, S.M., Smith, C.W. 2013. Debt and taxes: Evidence from the real estate industry. Journal of Corporate Finance, 20, 74-93.

Bartholdy, J., Mateus, C. 2011. Debt and taxes for private firms. International Review of Financial Analysis, 20(3), 177-189.

Blundell, R., Bond, S. 1998. Initial conditions and moment restrictions in dynamic panel data models. Journal of Econometrics, 87(1), 115-143.

Campos, A.L.S., Nakamura, W.T. 2015. Rebalanceamento da estrutura de capital: endividamento setorial e folga financeira. Revista de Administração Contemporânea, 19(spe), 20-37.

Chod, J., Zhou, J. 2013. Resource flexibility and capital structure. Management Science, 60(3), 708-729.

Choi, D.Y., Saito, R., Silva, V.A.B. 2015. Capital structure and staff salary: Empirical evidence in Brazil. Revista de Administração Contemporânea, 19(2), 249-269.

Clemente-Almendros, J.A., Sogorb-Mira, F. 2017. How much do the tax benefits of debt add to firm value? Evidence from Spanish listed firms. Revista de Economía Aplicada, 25(74), 105-129.

DeAngelo, H., Masulis, R.W. 1980. Optimal capital structure under corporate and personal taxation. Journal of Financial Economics, 8(1), 3-29.

Decree no. 3.000. (1999, 26 de março). Regulamenta o imposto. Brasília, DF: Presidência da República.Recovered from http://www.planalto.gov.br/ccivil_03/decreto/d3000.htm.

Devereux, M.P., Maffini, G., Xing, J. 2015. Corporate tax incentives and capital structure: Empirical evidence from UK tax returns. Oxford University Centre for Business Taxation, 15(7), 1-52.

Durand, D. 1952. Costs of debt and equity funds for business: Trends and problems of measurement. Chapter in Conference on Research in Business Finance. National Bureau of Economic Research, 215-262. http://www.nber.org/chapters/c4790.pdf.

Faccio, M., Xu, J. 2015. Taxes and capital structure. Journal of Financial and Quantitative Analysis, 50(3), 277-300.

Fan, J.P., Titman, S., Twite, G. 2012. An international comparison of capital structure and debt maturity choices. Journal of Financial and Quantitative Analysis, 47(1), 23-56.

Flannery, M.J., Hankins, K.W. 2013. Estimating dynamic panel models in corporate finance. Journal of Corporate Finance, 19(1), 1-19.

Frydenberg, S. 2011. Capital structure theories and empirical tests: An overview. Capital Structure and Corporate Financing Decisions: Theory, Evidence, and Practice, 15, 129150.

Godoi, M.S., Catarino, J.R., Melo, A.C., Garcia, A.C.M. 2017. Trends in international taxation on profits and dividends: A comparative study between Brazil and Portugal. Revista de Direito Internacional Econômico e Tributário, 12(1), 92-131.

Graham, J.R. 1996a. Debt and the marginal tax rate. Journal of Financial Economics, 41(1), 41-73.

Graham, J.R. 1996b. Proxies for the corporate marginal tax rate. Journal of Financial Economics, 42(2), 187-221. 
Graham, J.R. 2000. How big are the tax benefits of debt? The Journal of Finance, 55(5), 1901-1941.

Graham, J.R. 2003. Taxes and corporate finance: A review. Review of Financial Studies, 16(4), 1075-1129.

Graham, J.R., Tucker, A.L. 2006. Tax shelters and corporate debt policy. Journal of Financial Economics, 81(3), 563-594.

Graham, J.R., Leary, M.T., Roberts, M.R. 2015. A century of capital structure: The leveraging of corporate America. Journal of Financial Economics, 118(3), 658-683.

Hebous, S., Ruf, M. 2017. Evaluating the effects of ACE systems on multinational debt financing and investment. Journal of Public Economics, 156, 131-149.

Heider, F., Ljungqvist, A. 2015. As certain as debt and taxes: Estimating the tax sensitivity of leverage from state tax changes. Journal of Financial Economics, 118(3), 684-712.

Huang, R., Ritter, J.R. 2009. Testing theories of capital structure and estimating the speed of adjustment. Journal of Financial and Quantitative analysis, 44(2), 237-271.

Lara, J.E., Mesquita, J.M.C. 2008. Estrutura de Capital e Rentabilidade: análise do desempenho de empresas brasileiras no período pós Plano Real. Contabilidade Vista \& Revista, 19(2), 15-33.

Law no 11.638, de 28 de dezembro de 2007. Altera e revoga dispositivos da lei ${ }^{\circ} 6.404$, de 15 de dezembro de 1976, e da lei $n^{\circ} 6.385$, de 7 de dezembro de 1976. Diário Oficial da União, Brasília, DF. Recovered from http://www.planalto.gov.br/ccivil_03/_ato20072010/2007/lei/l11638.htm.

Law no. 12.814, de 16 de maio de 2013. Altera 9.718, de 27 de novembro de 1998. Regime de tributação com base no lucro presumido. Diário Oficial da União, Brasília, DF, 17/05/2013. Recovered from http://www.planalto.gov.br/ccivil_03/_ato20112014/2013/Lei/L12814.htm.

Li, S., Whited, T.M., Wu, Y. 2016. Collateral, taxes, and leverage. The Review of Financial Studies, 29(6), 1453-1500.

Locatelli, R.L., Nasser, J., Mesquita, J.M.C. 2015. Determining factors of the capital structure in agribusiness: The case of Brazil companies. Organizações Rurais \& Agroindustriais, 17(1), 73-86.

Martinez, A.L., Martins, V.A.M. 2016. Alavancagem financeira e agressividade fiscal no Brasil. Revista de Contabilidade da UFBA, 10(3), 4-22.

Miller, M.H. 1977. Debt and taxes. The Journal of Finance, 32(2), 261-275.

Modigliani, F., Miller, M.H. 1958. The cost of capital, corporation finance and the theory of investment. The American Economic Review, 48(3), 261-297.

Modigliani, F., Miller, M.H. 1963. Corporate income taxes and the cost of capital: A correction. The American Economic Review, 53(3), 433-443.

Myers, S.C. 1984. The capital structure puzzle. The Journal of Finance, 39(3), 574-592.

Myers, S.C., Majluf, N.S. 1984. Corporate financing and investment decisions when firms have information that investors do not have. Journal of Financial Economics, 13(2), 187221.

Oliveira, R.R.F., Gonçalves, M. 2015. The importance of tax planning for companies. Revista Científica e-Locução, 1(3), 36-44.

Pessôa, L.C., Muniz da Silva, M., Abreu Campanário, M.D. 2011. Tax cost of investment projects: The case of ICMS credits. Revista Brasileira de Gestão de Negócios, 13(38), 2140.

Richardson, G., Lanis, R., Leung, S.C.M. 2014. Corporate tax aggressiveness, outside directors, and debt policy: An empirical analysis. Journal of Corporate Finance, 25, 107 121. 
Roberts, M.R., Whited, T.M. 2013. Endogeneity in empirical corporate finance1. In Handbook of the Economics of Finance, 2. Part A, Chap. 7, 493-572. UK. Elsevier.

Shevlin, T. 1990. Estimating corporate marginal tax rates with asymmetric tax treatment of gains and losses. Journal of the American Taxation Association, 11(2), 51-67.

Thalassinos, I.E., Stamatopoulos, D.T. and Thalassinos, E.P. 2015a. The European Sovereign Debt Crisis and the Role of Credit Swaps. Chapter book in The WSPC Handbook of Futures Markets (eds) W. T. Ziemba and A.G. Malliaris, in memory of Late Milton Miller (Nobel 1990) World Scientific Handbook in Financial Economic Series Vol. 5, Chapter 20, pp. 605-639. DOI: 10.1142/9789814566926_0020.

Thalassinos, I.E., Thalassinos, E.P., Venedictova, B., Yordanov, V. 2015b. Currency Board Arrangement Capital Structure Macro-Financial Diagnostic. SSRN-id2624333.pdf.

Thalassinos, I.E. and Stamatopoulos, V.T. 2015. The Trilemma and the Eurozone: A PreAnnounced Tragedy of the Hellenic Debt Crisis. International Journal of Economics and Business Administration, 3(3), 27-40. DOI: 10.35808/ijeba/77.

Tian, Y. 2018. Optimal policy for attracting FDI: Investment cost subsidy versus tax rate reduction. International Review of Economics \& Finance, 53, 151-159.

Toy, N., Stonehill, A., Remmers, L., Wright, R., Beekhuisen, T. 1974. A comparative international study of growth, profitability, and risk as determinants of corporate debt ratios in the manufacturing sector. Journal of Financial and Quantitative Analysis, 9(5), 875-886.

Ugurlu, E., Thalassinos, E., Muratoglu, Y. 2014. Modeling Volatility in the Stock Markets using GARCH Models: European Emerging Economies and Turkey. International Journal of Economics and Business Administration, 2(3), 72-87. DOI: 10.35808/ijeba/49.

Wooldridge, J.M. 2018. Introductory econometrics: a modern approach. Ohio, Cengage Learning.

Zani, J., Leites, E.T., Macagnan, C.B., Portal, M.T. 2014. Interest on equity and capital structure in the Brazilian context. International Journal of Managerial Finance. 